\title{
Krystian Węgrzynek
}

Biblioteka Śląska w Katowicach

iD http://orcid.org/0000-0003-4453-6731

\section{Zachód czarnego słońca? $\mathrm{O}$ traumatycznych narracjach śląskich bohaterów}

\author{
Black Sunset? \\ On Traumatic Narrations of Silesian Characters
}

Abstract: The author describes the phenomenon of the sense of grievance deeply rooted in the Upper Silesian community. The starting point of the essay is a sociological diagnosis by Marian Gerlich, which dates the genesis of this phenomenon back to the interwar period of the 1920s and 1930s. The author of the article finds examples of historical and structural trauma (according to the distinction drawn by Dominick LaCapra) in the fortunes of some literary characters featured in the texts by Wilhelm Szewczyk, Szczepan Twardoch, Wojciech Kuczok, Stanisław Bieniasz and Leszek Libera. He observes the dynamics of the development of this trauma by referring it to the essay of Julia Kristeva (Black Sun. Depression and Melancholia). The title metaphor (le soleil noir) is the reverse side of the narration of Upper Silesia, standing in opposition to the official story (the obverse), monopolised by accounts of a successful symbiosis between a Silesian and his geographical and geopolitical environment. The author has focused on the fortunes of characters excluded from a large ethnic community, usually illegitimate or abandoned children - fortunes which - on a symbolic level - illustrate the relationship between "Homeland" and "Small Homeland". The expression "black sunset" is related to the tendencies, observed in the current discourse, to replace the "black" narration (glorifying exploitation) with the "green" narration and to diverge from images showing ethnic orphan hood to images depicting an autonomous community, conscious of its purposes.

Key words: Earth, mother, Silesia, trauma, orphanhood 
Streszczenie: Autor opisuje zjawisko poczucia krzywdy w społeczności górnośląskiej. Punktem wyjścia jest diagnoza socjologiczna Mariana Gerlicha, który genezę tego zjawiska lokuje w epoce międzywojennej. Przykłady traumy o charakterze historycznym i strukturalnym (według podziału Dominicka LaCapry) odnajdywane są w losach bohaterów tekstów literackich Wilhelma Szewczyka, Szczepana Twardocha, Wojciecha Kuczoka, Stanisława Bieniasza i Leszka Libery. Autor śledzi dynamikę rozwoju tej traumy, odnosząc ją do eseju Julii Kristevej (Czarne słońce. Depresja i melancholia). Tytułowa metafora (le soleil noir) stanowi rewers narracji o Górnym Śląsku, konfrontacyjnej wobec oficjalnej opowieści (awersu), w której dominują historie o udanej symbiozie Ślązaka z otaczającym go środowiskiem geograficznym i geopolitycznym. Autor koncentruje się na losach bohaterów wykluczonych z wielkiej wspólnoty etnicznej, zazwyczaj bękartach lub dzieciach porzuconych, będących - w planie symbolicznym - ilustracją relacji wielka ojczyzna - mała ojczyzna. Określenie "zachód czarnego słońca" odniesione jest do obserwowanych w aktualnym dyskursie tendencji - do zastępowania narracji „czarnej” (apoteozującej eksploatację) narracją „zieloną" oraz do odchodzenia od obrazów eksponujących sieroctwo etniczne do obrazów pokazujących obraz wspólnoty autonomicznej i świadomej swoich celów.

Słowa kluczowe: Ziemia, matka, Śląsk, trauma, sieroctwo

W powieści Czarne słońce Wilhelma Szewczyka ${ }^{1}$ opisu słonecznego dnia raczej nie znajdziemy. Albo „czerwony świt” sączył się „wąziutką strużką" (Cs, s. 66), albo niebo zasnuwały „żółte proporce dymów”, bo „kominy kopalni dymiły bez przerwy” (Cs, s. 110), a płomienie pozostawiały po sobie "kulkę czarnego dymu, jak po pocisku przeciwlotniczym" (Cs, s. 183). Jaskrawy optymizm zostaje więc umieszczony na tle zdecydowanie przeczernionym. Ba, nawet w scenie końcowej powieści - przejęcia kopalni pod koniec II wojny światowej w Czerwonej Wodzie (śląscy i radzieccy komuniści odbijają ją z rąk śląskich i niemieckich hitlerowców) - towarzyszy adekwatny opis:

Dym walił z wszystkich kominów, łączył się w czarną, gęstą chmurę. Ostre jeszcze przed chwilą słońce matowiało powoli. Przesłaniał je dym, ciągnący po wyjaśniałym niebie. Słońce świeciło czarnym, aksamitnym blaskiem [...]. Od dymu pociemniało całe niebo, czarne słońce odcinało się jedynie zewnętrznym srebrnym krążkiem.

Cs, s. 432

${ }^{1}$ W. Szewczyк: Czarne słońce. Warszawa 1953. Dalej, lokalizując cytaty z tej powieści, po skrócie Cs podaję stronę. 
Cóż to oznacza? Trwa wydobycie - a jakże! Znajdujemy się wszak w świecie powieści produkcyjnej. A jednak tytuł niepokoi! Przecież w tym brudzie tkwi oścień śmierci, w tym „marasie” jest „mors”, powiedziałby Mariusz Jochemczyk². To wszystko dzieje się jednak za plecami bohatera, niejako poza jego świadomością.

Od tego obrazu śląski bohater odwracał się nieraz: „Przekleństwo! I jeszcze raz płonące hałdy, skurczone postacie wlokące taczki żelastwa, zmatowiałe oczy, blady, suchotniczy świat. [...] Oto Górny Śląsk. Nigdy tu nie wrócę - przenigdy!"3. Wydrążona Matka Ziemia wypluwa z siebie górnika z podbytomskiego Szarleja (bohatera tekstu), tak samo wydrążonego jak ona i plującego taką samą czarną żółcią jak śląscy górnicy z Czerwonej Wody.

Awers błyszczy w sentencji staruszki, współczującej zjeżdżającym do kopalni górnikom: „Niech ludzie przebywają na powierzchni ziemi, gdzie słońce Boże świeci [wo Gottes Sonne scheint]"4. To samo zresztą przeczytamy w Aurelii Gérarda de Nervala: „Bóg to słońce" ${ }^{\prime \prime}$ - odpowiada narratorowi wujek.

Nervalowską metaforę, czarne słońce ${ }^{6}$, symbol rewersu opowieści, będę zestawiał ze śląskim le soleil noir; w śląskich tekstach sprzed bez mała wieku jest ono elementem krajobrazu, ale z wolna staje się częścią pejzażu duszy.

Dwie strony tej narracji wyraźne są w zestawieniu dwóch scen z tekstów międzywojennych: w finale Wyrąanego chodnika Gustlik „urzeczony cudem słonecznego dnia”7 (dnia uroczystego wejścia polskiego wojska na górnośląską ziemię) zawiesza biało-czerwony sztandar na szycie hutniczego komina. Z kolei bohater poematu Wilhelma Szewczyka pt. Hanys wspina się na komin kopalni (w środku kryzysu gospodarczego!) i rzuca się w dół, popełniając samobójstwo. W utworze Morcinka obdarzony wolą mocy bohater wydobywa czarne złoto i wyrąbuje chodnik do wolności, a zatruty czarną żółcią protagonista Szewczyka, rozczarowany Polską, odbiera sobie życie

2 Zob. M. Јоснемсzүк: Wobec tradycji. Ślaskie szkice oikologiczne. Katowice 2015, s. $58-59$.

${ }^{3}$ H. Marchwitza: Moja młodość. Tłum. O.A. Ziemińscy. Warszawa 1950, s. 143.

${ }^{4}$ H. NowaK, G. Zivier: Zink wird Gold. Ein Roman des wirklichen Lebens. Berlin 1937, s. 6. Tu i dalej - o ile nie zaznaczono inaczej - tłum. z języka niemieckiego - K.W.

${ }^{5}$ G. de Nerval: Aurelia. W: Idem: Śnienie i życie. Tłum. R. Engelking, T. SwoBODA. Gdańsk 2012, s. 107.

${ }^{6}$ Nervalowskie czarne słońce „staje się synonimem wszechogarniającej pustki". Zob. P. Śniedziewski: Czarne słońca romantyków. Warszawa 2018, s. 98.

${ }^{7}$ G. Morcinek: Wyrabany chodnik. Wrocław 1997, s. 520. 
w wigilijną noc ${ }^{8}$. Czy zatem przyjrzenie się obu stronom narracji ma swoje uzasadnienie? Czy wysłuchanie całej opowieści nie pozwoli przygotować się na powrót wypartego? Czy też jesteśmy skazani na "Zwichniętą symetrię"

Sytuacja śląskiego bohatera widziana z perspektywy nie industrialnej, a agrarnej, eksponuje inny wymiar tego samego dramatu:

Na Miarkach [...] miały być zlokalizowane szyby, sortownia, łaźnie i inne budynki kopalni. Gdy Ludwik Szuster usłyszał, za jaką cenę musi oddać państwu ziemię, ukląkł na swej ojcowiźnie, ręce wzniósł do nieba i rozpaczliwie zapłakał: „Ziymiczko rodzono, tyś nos bez całe wieki żywiła, a my cie teroz muszymy oddać. My by cie nigdy niy opuścili, za żodne skarby, ale widzisz, że muszymy. Przebocz nom! Tyn marny grosz, jaki nom z łaski wyciepnom, przełożymy na klosztory"10.

Rolnik z Miarek, tym razem zwracając się do ziemi, również musi ją porzucić; zostaje wykorzeniony, a stara agrarna opowieść o związku człowieka z ziemią zostanie zastąpiona przez narrację industrialną 11 .

Czy śląski bohater nie marzy dzisiaj o drodze przeciwnej do tej, którą pokonuje protagonista Unsere Jana Darowskiego?

U nas były [liście w Brzeziu - K.W.] wspaniale zielone. Za Rybnikiem robiły się siwe, w Katowicach były już ciemnoszare. A w Chorzowie [...] bliżej czarnego koloru ${ }^{12}$.

Czy ten wynaturzony bohater nie chciałby odczernieć (jak górnik po wyjściu z łaźni łańcuszkowej) i zzielenieć (jak utopek), a przynajmniej zatrzymać się na etapie pośrednim, osiwieć. Jak obiecująca prognoza w tym kontekście brzmią słowa Ingmara Villqista:

Podobno Śląsk wygląda z góry jak jaki bezkresny ogród; tak intensywnie zielony, że aż trudno uwierzyć, iż kolor ten mieć może taką nieskończoność odcieni, walorów i temperatur.

${ }^{8}$ Zob. W. Szewczyк: Hanys. Noc. Katowice 1963, s. 29-30.

9 R. WojaczeK: ***[,Ludzie kładą się spać...”]. W: Idem: Wiersze zebrane. Red. B. KiERC. Wrocław 2006, s. 10.

${ }^{10}$ A. Lysкo: Nasze dziedzictwo. Bieruń 2005, s. 137.

${ }^{11}$ Narrację industrialną, której awers i rewers już znamy.

12 J. Darowski: Unsere. Posłowie A. Jakubowska-Ożóg. Rzeszów 2012, s. $98-99$. 
[...] może swoją zielonością coś usprawiedliwia, tłumaczy, albo zmyślnie skrywa. Ale przed kim? Tylko ptaki patrzą każdego dnia na śląski ogród z tak wysoka, piloci, no i Pan Bóg, więc to chyba przed jego wzrokiem ten zielony kamuflaż $\dot{z}^{13}$.

Ten obraz wyrasta z tęsknoty - przecież z tego ogrodu „przyszliśmy" - źródłem tej tęsknoty jest pradawna utrata, a tak ukształtowane cierpienie ma charakter "strukturalny". O traumie strukturalnej Dominick LaCapra pisze: „We wszystkich tych scenariuszach pojawia się ten sam problem, a mianowicie zamienianie nieobecności w utratę lub brak, zazwyczaj za sprawą koncepcji rozpadu domyślnego stanu łaski, swojskości, jedności i wspólnotowości"14. Autor nie rozdziela jednak zdecydowanie traumy mającej swe korzenie $\mathrm{w}$ mitycznych źródłach od tej rodzącej się w wyniku burz dziejowych ze względu na wymykającą się definitywnemu określeniu istotę zjawiska: „Ważną motywacją dla zrównania traumy strukturalnej z historyczną jest nieuchwytność doświadczania traumatycznego"15.

Jak się sprawy mają $\mathrm{w}$ interesującym nas przypadku? Socjolog początków ,"śląskiej krzywdy"16 nie szuka w okresie XIX-wiecznego industrialnego boomu, a w epoce międzywojennej, czyli wtedy, gdy część regionu została „przyłączona do Macierzy”. Marian Gerlich w głośnym artykule ${ }^{17}$ wskazuje kilka źródeł poczucia krzywdy:

- posądzenia o separatyzm i indyferentyzm narodowościowy,

- wieloaspektowa eksploatacja ziemi śląskiej,

- jednostronna prezentacja śląskiej zbiorowości, tzn. prezentacja ograniczona tylko do etnicznej polskości górnośląskiej grupy regionalnej,

- niedocenienie wysokich kwalifikacji zawodowych,

- upadek mitu „Polski sprawiedliwej”,

- poczucie wykorzystania i poniżenia („nos mieć za niewolników, a ta ziemia [...] za jakoś afrykańsko kolonia"),

- irytacja wielkopańskim stylem życia przybyszów, napływowej elity,

${ }^{13}$ I. Villoist: Czarne i zielone. „Fabryka Silesia” 2016, nr 1, s. 94.

${ }^{14}$ D. LaCapra: Trauma, nieobecność, utrata. Przeł. K. Bojarska. W: Antologia studiów nad trauma. Red. T. Łysak. Przeł. T. Bilczewski, K. Bojarska, J. Burzyński, A. Kowalcze-Pawlik, A. Rejniak-Majewska. Kraków 2015, s. 99.

${ }^{15}$ Ibidem.

${ }^{16}$ LaCapra pisze też o traumie założycielskiej, która służy jako „podstawa tożsamości zbiorowej i jednostkowej, albo obu. Zagłada, niewolnictwo czy apartheid - a nawet cierpienie z powodu skutków bomby atomowej w Hiroszimie i Nagasaki - mogą stać się traumą założycielską". Ibidem, s. 103.

${ }^{17}$ M. Gerlich: Ślaska krzywda. „Etnografia Polska” 1994, z. 1-2, s. 5-21. 
- pomijanie Ślązaków w procesie awansu społecznego,

- poddawanie krytyce idei Ojczyzny prywatnej (kosztem Ojczyzny ideologicznej),

- deprecjonowanie śląskich obyczajów i śląskiej mowy,

- hańbiące potraktowanie Wojciecha Korfantego „niekwestionowanego przywódcy ludności rodzimej".

Na poczucie krzywdy śląskiego bohatera składają się zatem dwa rodzaje odrzucenia: wykorzenienie (odrzucenie przez Matkę Naturę) i wydziedziczenie czy też odtrącenie przez Matkę, by tak to ująć, Etniczną ${ }^{18}$.

W planie symbolicznym te interakcje przedstawiane sa jako relacje matki z dzieckiem. Jeszcze w XIX wieku katolicka partia Centrum przedstawiana była jako macocha śląskiego ludu. $\mathrm{W}$ propagandzie niemieckiej po 1918 roku popularny był Rabenmutter-Motiv, czyli motyw Polski wyrodnej matki, która wyrzekła się swojego dziecka Śląska ${ }^{19}$.

W tekstach polskich tego okresu Matką, Macierzą, do której Śląsk wraca po latach „oderwania” ${ }^{20}$, była Polska. Śląsk w tekstach polskoi niemieckojęzycznych przedstawiany był (i jest) zaś jako dziecko porzucone czy osierocone. Śląski bohater stawał się melancholikiem wyrosłym z choroby sierocej ${ }^{21}$.

Przypadłości dorastającego sieroty spajane są narracją spod znaku czarnego słońca, jest to jednak melancholia nie tak mroczna jak Ner-

${ }_{18}$ Awersem tej opowieści jest narracja o wielowiekowym czasie oczekiwania na wolną Polskę, ukazana poprzez motyw śpiącego wojska św. Jadwigi. Zob. np. K. WęGrzyneK: Języki mitu, historii, religii na Górnym Śląsu. Katowice 2018, s. $178-180$.

19 Zob. Z. Zielonka: Śląsk - ogniwo tradycji. Katowice 1981, s. 317.

${ }^{20} \mathrm{~W}$ poemacie Wilhelma Szewczyka Hanys Polska jawi się m.in. jako "sina wdowa”, a zrozpaczony bohater "ma w ustach nędzę wszystkich biednych". Zob. W. Szewczyк: Hanys..., s. 14 i 28. Z kolei Wyrabany chodnik Morcinka kończy się sceną, w której wkraczającemu na Śląsk wojsku towarzyszy westchnienie spodziewającej się dziecka Helenki: „Nowe życie” - to ostatnie słowa powieści. Zob. G. Morcineк: Wyrabany chodnik..., s. 520. Ale gdyby nawet czytać samego Szewczyka, i to w duchu głęboko pesymistycznym, to na tym tle wyznanie początkowe Nervala (,Ja-mroczny, ja-wdowiec, mnie-nikt ulżyć nie może”) brzmi dalece bardziej depresyjnie - jego beznadziejne wdowieństwo staje wobec jakiegoś rodzaju usynowienia śląskiego sieroty.

${ }^{21} \mathrm{~W}$ literaturze przedmiotu zwraca się uwagę na wiele rodzajów choroby sierocej i towarzyszących jej objawów. Wymienię ich kilka: osamotnienie, lęk, poczucie niższości, wycofanie się, brak emocjonalnego zaangażowania, brak poczucia przynależności, poczucie pejoratywnej odmienności. Zob. M. Рroкosz: Choroba sieroca. Gdańsk 2010, s. 50-61. 
valowska - śląskie sieroctwo nie dojrzewało w mroku sześciuset lat germanizacji, przeglądało się przecież nierzadko w blasku czarnego złota. Niemniej pod grubą pokrywą wielowiekowego sieroctwa, pod ciężkim płaszczem ideologii i solidną maską sowizdrzalskiej rubaszności kryje się ciągle melancholia. Zajrzyjmy głębiej, choć to ukryte ,ja" może nie sprawia takiego wrażenia ${ }^{22}$ : jaka strata zmieniła życie śląskiego bohatera? Jakiej żałoby nie przepracował? Tęsknota do Bożego słońca? Porzucenie czy zaniedbanie przez rodziców (prawdziwych i przybranych). Opuszczenie ich? Tęsknota za dawną, wielokulturową wspólnotą (czy bezgraniczna wiara w mit, że taka wspólnota istniała)? Ta nieokreśloność wpisana jest przecież w melancholię. Melancholik „nie wie [...], nawet gdy zna obiekt straty, co w nim utracił i jego praca żałoby nie może się dokonać" ${ }^{23}$.

Genezę tych przypadłości opisuje Szczepan Twardoch w Wiecznym Grunwaldzie $e^{24}$. Protagonista przedstawia się następująco: "Jeśm ja Paszko. Króla Kazimira bastert [...] Pogrobkiem jegośm" (WG, s. 136). Matką jest córka norymberskiego kupca, ale w powszechnej świadomości Paszko będzie dla Niemców „Hurensohn”, a dla Polaków „kurwie macierze syn” (WG, s. 136). I mimo że Kazimierz Wielki zrzekł się Śląska na rzecz Korony Czeskiej już na początku swego panowania, to bohatera powieści można traktować, szczególnie w kontekście całej twórczości Twardocha, jako porzucone śląskie dziecko (Śląsk w ogóle), oderwane od Matki/Macierzy czy, ściślej rzecz ujmując, porzucone przez Ojca/Ojczyznę. I tylko w marzeniach jest to egzystencja spełniona:

Potem było życie inne, gdzieś w cieniu, ledwo mogłem je odtworzyć i zobaczyć, życie, w którym mój ojciec - król - nie umarł i z tego pnia wyrastały gałęzie, w których byłech kimś zupełnie innym: nosiłem podbite jedwabiem futra, ornaty i zbroje.

WG, s. 11; podkr. - K.W.

Paszko jest zatem wydziedziczony, ale pozostaje w nim pamięć szlachetnej przynależności, która kiedyś - jeśli traktować go jako

${ }^{22}$ „W wypadku żałoby to świat zubożał i opustoszał, w wypadku melancholii zubożało i opustoszało samo "ja«". Z. Freud: Żałoba i melancholia. W: Idem: Psychologia nieświadomości. Tłum. R. Reszke. Warszawa 2007, s. 149.

${ }^{23}$ M. BıеŃczyK: Melancholia. O tych, co nigdy nie odnajda straty. Warszawa 2000, s. 16.

${ }^{24}$ S. Twardoch: Wieczny Grunwald. Warszawa 2011. Dalej, cytując fragmenty z tego utworu, posługuję się skrótem WG i podaję strony. 
synekdochę - obudzi się w innym, habsburskim kontekście jako „perła w koronie" 25 .

W świadomości bohatera-narratora konfrontowane są obie strony śląskiej opowieści:

Czarne bogi siedzą na moich ramionach: na lewym Zmej, na prawym zaś Perun, i mruczą mi do ucha swoje stare pieśni i pieśń Zmeja, pieśń ziemi, pieśń wilgotna wygrywa z pieśnią słońca, nieba i piasku. I walczę źle, bez słonecznego miłosierdzia, z którym ruszał do bitwy Ardżuna, zabijam z nienawiści [...].

$$
\text { WG, s. 180; podkr. - K.W. }
$$

Pieśń spod znaku le soleil noir okazuje się donośniejsza niż hymn słoneczny, ale, wyrastając z „pnia zemsty"26, ukojenia bohaterowi przynieść nie może.

O ile Paszko ostatecznie ponosi jednak rycerską śmierć na polach Grunwaldu, walcząc „pod słońcem szatana”27, o tyle protagonista powieści Augusta Scholtisa skazany jest na żywot nieopromieniony nawet takim blaskiem.

Kacparek zamiast Kacper mówili mu sąsiedzi, Tyl zamiast Teofil nazywała go reszta wsi. Kaczmarek, jak powszechnie wiadomo, nazywali go Prusacy i mówiono tak w innych ościennych krainach. By wymazać i ponownie zaszczepić jego smutne wspomnienie. Człapu-człap. A słońce prażyło w gnojowisko ${ }^{28}$.

Bohater los ma już zapisany w swoim nazwisku (dla Niemca z początku XX wieku Kaczmarek to synonim prostackiego, niedouczo-

${ }^{25}$ Ch. Garve: O położeniu Śląska w rozmaitym czasie oraz o zaletach stolicy względem miast prowincjonalnych. W: Ślask. Rzeczywistości wyobrażone. Red. W. KunICKI przy współpracy N. i K. Ż̇arskich. Poznań 2009, s. 107.

${ }^{26}$ Por. „Z pnia owego drzewa zemsty i nienawiści, nienawiści żydowskiej [...] wyrosło coś również bezprzykładnego, nowa miłość”. F. Nietzsche: Z genealogii moralności. Pismo polemiczne. Tłum. L. Staff. Kraków 2003, s. 22.

${ }_{27}$ "Czarne słońce to diabelski znak". Zob. P. Śniedzıewski: Czarne słońca..., s. 98. Oczywiście walka śląskiego bękarta to bohaterstwo zupełnie innego rodzaju niż heroizm proboszcza z Lumbres. Rola księdza w lokalnych narracjach to temat na osobną rozprawę, w której powieść Georgesa Bernanosa byłaby interesującym punktem odniesienia.

28 A. Scholtis: Wiatr od wschodu. Tłum. A. Smolorz. Kotórz Mały 2015, s. 16. Dalej cytaty z tego utworu lokalizuję, podając skrót W i strony. 
nego Wasserpolaka) i imieniu (Tyl - to wcielenie Dyla Sowizdrzała). Dla Scholtisa to oczywiście rodzaj gry ze stereotypem, gry przeprowadzanej bez żadnego znieczulenia: bity, opluwany i wyszydzany Kaczmarek, który początkowo przecież „był bez żółci” ${ }^{29}$, nasiąka nią tak bardzo, że pozbywa się jej z naddatkiem: a to poprzez różnego rodzaju „złośliwość wesołą" ${ }^{30}$, a to poprzez sadystyczne okrucieństwo (posypuje rany schwytanego powstańca solą i pieprzem - W, s. 311), a to poprzez masochistyczne żarty (,- Na co pan sobie pozwala, Polaczku? - Szmaciarzu - poprawił Kaczmarek - Czy macie szmaty do wydania?"; W, s. 189).

Opada jednak łotrzykowska maska, rozpada się kreacja wielkiego prześmiewcy, gdy Sowizdrzał wspomina traumę pierworodną:

Moje ręce są puste, a ja jestem gotów umrzeć za prawdę. [...] Stanąłem na wieży kościelnej mojego dzieciństwa i patrzę za tobą na horyzont, wietrze... [...] Wietrze... ze wschodu, spójrz na mnie. Moja wieża kościelna ugina się i chwieje.

W, s. $426-427$

Ta wertykalna, niebiańska nieomal konstrukcja rozpada się na gruncie rzeczywistości. To samo dzieje się z podmiotem El Desdichado Nervala (,Ja, książę Akwitanii o zniesionej wieży / Jedyna gwiazda zgasła w lutni gwiazdozbiorze"31) i z Wojaczkowym bohaterem, któremu edeńska obietnica życia wymyka się z rąk („Ja książę Akwitanii / wspinam się na drzewo / [...] Potem spadłem z drzewa"32). W ujęciu terapeutycznym można by te obrazy potraktować jako rozpoznanie i opłakanie złudzeń, a więc przeprowadzanie pracy żałoby, jako wykonywanie ciągłego ruchu między „nieświadomym zaczarowaniem a elementem rzeczywistości"33.

Podobny mechanizm można zauważyć w powieści Der Utopek Leszka Libery ${ }^{34}$, książce napisanej $\mathrm{w}$ języku niemieckim przez pol-

${ }^{29}$ H.J.Chr. von Grimmelshausen: Przygody Simplicissiusa. Tłum. A.M. Linke. Warszawa 1958, s. 89.

${ }^{30}$ K. DE Coster: Przygody Dyla Sowizdrzała. Tłum. J. Rogoziński. Wrocław 1993, s. 64.

${ }^{31}$ G. De Nerval: El Desdichado. Tłum. A. Ważyк. W: Antologia współczesnej poezji francuskiej. Oprac. A. WАżYK. Warszawa 1947, s. 26.

${ }^{32}$ Ibidem.

${ }^{33}$ D. Kalsched: Wewnętrzny świat traumy. Archetypiczne obrony Jaźni. Tłum. M. Kalinowska. Poznań 2015, s. 242.

34 L. Libera: Der Utopek. Roman. Dresden 2011. 
skiego autora ${ }^{35}$. Akcja utworu toczy się w Raciborzu po zakończeniu II wojny światowej. Czytelnik poznaje dokładniej bohatera, kiedy ten przedstawia się urzędnikowi przyjmującemu go do szkoły jako Buks (to znowu nie imię własne, a śląskie określenie gałgana, łobuza, psotnika), Molenda. Rozmowa z notablem jest męcząca - zamiast Buksa odpowiada matka, której syn szczerze nienawidzi. Dla obojga bolesne są pytania o drugiego z rodziców chłopca: „Imię ojca. Pytam o ojca! - krzyknął rozgniewany, przewiercając ołówkiem kawałek papieru. Matka spojrzała na niego jadowicie" ${ }^{\prime 36}$. Kolejny to więc, po Paszku i Kaczmarku, śląski podrzutek - „podciep”. Następny, który nie potrafi odnaleźć się w języku:

- Język ojczysty? ${ }^{37}$ Czy umie mówić po polsku? [...] wrzasnął i przeliterował głośno: Niedorozwinięty fizycznie i umysłowo. A więc I.A. Schule dla Germanów i idiotów! - krzyknął rozgniewany i uradowany zarazem kazał podpisać matce ten kawałek papieru i wypędził nas ${ }^{38}$.

U, s. 21

Moment wypędzenia staje się dla Buksa początkiem symbolicznego wycofania, chciałoby się rzec, że powrotem do natury - chłopiec staje się utopkiem - ale i natura śląskiego bohatera przyjąć nie chce: „Przeszliśmy przez most, Odra cuchnęła gównem, żaden utopek nie mieszkał w Odrze, bo utopki są wrażliwe na odór gówna [...]. Było ciepło i sucho, ukryłem się więc w beczce" (U, s. 22).

Pełne bólu milczenie czy dokładniej: nieumiejętność odnalezienia własnego języka (języka ojczystego/Muttersprache), nieumieszczanie swojej traumy w narracyjnych ramach pogłębia chorobę śląskiego

${ }^{35}$ Libera problem wydziedziczenia eksponuje już w tytule powieści. Podobnym mechanizmem posługuje się Nerval w hiszpańskim tytule swojego wiersza - El Desdichado.

${ }^{36}$ L. Libera: Utopek. Tłum. S. Lisiecka. Łódź 2018, s. 21. Dalej cytaty z tego utworu opatruję skrótem U, po którym podaję strony.

${ }^{37}$ Nieco inaczej brzmi ten dialog w oryginale. Nauczyciel najpierw pyta o ojca („Name des Vaters, fragte er"), a następnie pyta matkę i syna o język ojczysty („Muttersprache, fragte er dann”). Zatem syn nieznający ojca, nie określa języka matki. W tekście przekładu sfera wydziedziczenia w większym stopniu dotyczy strony ojca i języka ojczystego. Por. L. Libera: Der Utopek..., s. 21-22. Wszystkie podkreślenia - K.W.

${ }^{38}$ Opis polskiej, komunistycznej szkoły jest jakby rewersem opisu szkoły pruskiej, gdzie idiotami byli ci, niemówiący po polsku (tak jest chociażby w Wietrze od wschodu). 
bohatera. I Leszek Libera nie ukrywa, że jego protagonista jest pars pro toto całej wspólnoty, bowiem utopki „,są wspaniałą rasą, czysto śląską tajemniczą i niepokonaną" (U, s. 137). Dodajmy - słońca unikającą; dorzućmy jeszcze - za Zbigniewem Kadłubkiem - to rasa utopijna, żyjąca mrzonkami o "górnośląskim etnicyzmie" ${ }^{39}$.

Bynajmniej nie marzy o nim bohater Gnoju Wojciecha Kuczoka. Ślązacy jawią się jako gatunek, który ma skłonność popadania w pułapki mimikry ${ }^{40}$. Jakoś zakorzeniony w lokalności jest ród $\mathrm{K}^{41}$, ale syn starego K. czuje się od samego początku na świat (na ojca) skazany. „Czułem, że własna matka mnie wydała i żadną mi nie było pociechą to, że wydała mnie na świat. Świat, w którym pierwszą osobą, bezgranicznie zniecierpliwioną moją nieobecnością był stary K." (G, s. 186).

Wydany na świat/światu bohater, już po wszystkim, po katastrofie domu, potopie fekaliów, chce uciec od cienia domu: „w im bardziej świetliste miejsca trafiałem, tym bardziej mnie cień naznaczał" (G, s. 212). Unika słonecznego świata jak Buks „Utopek” Molenda, jak Kaczmarek i Paszko.

Śląski bohater z tej ciemnej strony opowieści jawi się jako potomek niechciany, zraniony, wzgardzony, dorastający w poczuciu niezrozumienia. Ale czasem znajduje się w sytuacji dziecka (nawet dorosłego!) skłóconych rodziców, które zmuszone jest do opowiadania się po jednej stronie i przeciw drugiej. W dyskursie historycznym to próba - przede wszystkim dla mieszkańców dawnego pruskiego Śląska - określenia swojej pozycji w odwiecznym, polsko-niemieckim Grunwaldzie.

W takim polsko-niemieckim rozdarciu stają bohaterowie książek Stanisława Bieniasza. Tak jest np. w powieści Niedaleko Königsalee:

39 Z. Kadєuвек: Utopijne utopce. „Fabryka Silesia” 2013, nr 1, s. 91.

40 Przykładowo po 1939 roku: „Ale wojna nie rozdeptała ani jednego domu w okolicy, wszyscy mieszkańcy miasta okazali się szczęśliwymi mieszkańcami terytorium natychmiast uznanego za odwiecznie niemieckie, wszyscy mieszkańcy regionu przy odrobinie woli okazali się szczęśliwymi odwiecznymi Niemcami, mogli się oczywiście sprzeciwiać temu stanowi rzeczy, mogli dobrowolnie pakować w tarapaty, ale mieli ten komfort obcy wielu mniej szczęśliwym regionom kraju, że ich domów nie burzono bez pytania [...]". W. Kuczok: Gnój. Warszawa 2010, s. 51. Dalej cytaty z tej powieści lokalizuję, posługując się skrótem $\mathrm{G}$ i podając strony.

${ }^{41}$ „Ojciec starego K. był człowiekiem wydrążonym; miał korzenie, miał gałęzie, miał swoje miejsce $\mathrm{w}$ ogrodzie, ale w środku był pusty, w środku mógł tylko sam się chować przed światem, zamykać, ryglować, wsiąkać" (G, s. 55). 
Męczyła mnie z początku nostalgia. Wie pan, co to jest? „Litwo, ojczyzno moja...". Litwa znaczy w tym kontekście to samo, co Heimat $\mathrm{w}$ razie gdyby pan tego nie rozumiał [...]. Stałem się heimatlos, pozbawiony swego miejsca na ziemi [...]. Heimat to coś, co człowiek nosi w sobie i to są wspomnienia z dzieciństwa. Horst Bienek to napisał. Czytał pan? ${ }^{42}$

Główny bohater tej nostalgicznej prozy - Willi Kulpa, przypominający samego Bieniasza, rozdarty pomiędzy Düsseldorfem a Zabrzem, przeżywa podobny dramat niezakorzenienia co porte-parole Scholtisa - Kaczmarek. Pierwszy wyjeżdża z polskiego (PRL-owskiego) Górnego Śląska, próbując odnaleźć się w Niemczech, drugi przyjeżdża do Polski (Ludowej), usiłując dostrzec swój dawny Śląsk niemiecki ${ }^{43}$. Relacje ich obu z Wielką Matką Etniczną, panującą $\mathrm{w}$ powojennych strukturach państwowych szczególnie serdeczne przecież nie są. Dzisiaj, kiedy nie ma już zachodnich Niemiec i komunistycznej Polski, te i inne relacje mogłyby na pewno się poprawić. Czy tak się stanie? To temat na osobną rozprawę.

Choć tytuł niniejszego tekstu mógłby być także zwiastunem optymistycznej wizji dobrosąsiedzkich stosunków polsko-niemieckich, a śląski bohater rzecznikiem pojednania, tytuł tego tekstu odnosi się jednak przede wszystkim do opowieści o losie Ślązaka wydziedziczonego i wykorzenionego. Ten los to bycie w cieniu, wegetacja pod tarczą czarnego słońca, a ta metafora, zdaniem Julii Kristevej, "dobrze oddaje oślepiającą siłę smutnego nastroju"44. Sądzę jednak, że to Sol Niger w śląskim kontekście silniej oddziałuje poprzez swoją niejednoznaczność. $Z$ jednej strony niepokojące światło czarnego słońca zniechęcało do wyjścia $z$ własnoręcznie wydrążonego piekła, z zapełnionej cieniami jaskini, z drugiej - dawało poczucie dumy z dokonanej pracy. Tę część słonecznej opowieści o Górnym Śląsku snuto niejednokrotnie. Trudno nie było jej usłyszeć w przedwojennych gawędach Stanisława Ligonia, prozie Gustawa Morcinka czy powojennych pieśniach zespołu Śląsk.

Tak rozumiany oksymoron (czarny ogród, czarne złoto z jednej strony, a czarne słońce, czarna żółć - z drugiej) uznaję zatem za odpowiedni trop wyrażający ducha wspólnoty. By obraz był pełny, przywołajmy jeszcze tę figurę zapisaną w czeskiej części Śląska:

\footnotetext{
42 S. Bieniasz: Niedaleko Königsalee. Katowice 1997, s. 101-105.

${ }^{43}$ Zob. A. Scholtis: Reise nach Polen. Ein Bericht. München 1963.

${ }^{44}$ J. Kristeva: Czarne słońce. Depresja i melancholia. Tłum. M.P. Мarкowsкi, R. RYZı́́sKi. Kraków 2002, s. 152.
} 
Sto lat w kopalni ja pod ziemią

Żyłem, w milczeniu swym zapiekły [...]

Węglowy pył mi oczy zasnuł i w wargi wżarł się czarny kamień [...]

Zabieram z węglem chleb do pracy ${ }^{45}$

Czarny, węglowy chleb spożywany jest w milczeniu... Kiedy Aleksander Nawarecki i Stefan Szymutko na przełomie XX i XXI wieku ogłaszali, że śląski Logos milczy ${ }^{46}$, diagnoza ta powszechnie uznawana była za trafną. Szymutko pisał wręcz o śląskim bohaterze: „Człowieka ufającego naturze zastąpiło stechnicyzowane zwierzę ${ }^{\prime 47}$. To zwierzę, które przestało mówić ludzkim językiem, nabrzmiewało ciągle „niewypowiedzianym”. Wzbierające milczenie w końcu jednak pęka; kruszy się wraz z nim - jak to ujęła językoznawczyni i psychoanalityczka - „krypta niewypowiedzianego uczucia"48. Pęknięcie to zaś zapowiada istotną przemianę: „Pamiętajmy, że rozdzielenie $\mathrm{z}$ obiektem rozpoczyna tak zwaną fazę depresyjną. Tracąc matkę i opierając się na negacji, odzyskuje ją jako znak, obraz, słowo"'49. Bohater nie mógł opowiedzieć o matce "językiem martwym", bohater milczący nie mógł jej odnaleźć w opowieści. Ten naturalny związek zastępuje dziś wytworzona relacja. Michał Paweł Markowski pisze:

Tym, co pozwala umknąć piekłu melancholii, jest więc wspólnota, wspólnota realna (inni ludzie) i wspólnota wyobrażona (sztuka). Literatura jest przestrzenią wyobrażonej wspólnoty, w której nikt nie jest sam $^{50}$.

Narracja traumatyczna zawarta w wielojęzycznej literaturze śląskiej to zarazem narracja wynaturzenia i wydziedziczenia, sieroc-

45 P. Bezruč: Ostrawa. Tłum. W. Zıемba-WojciechowsKa. W: 99 ksią̇̇ek, czyli mały kanon górnoślaski. Red. Z. KADŁubeK. Katowice 2011, s. 42.

46 A. Nawarecki: Lajerman. Gdańsk 2010, s. 20; S. Szymutкo: Nagrobek ciotki Cili. Katowice 2001, s. 35.

47 Ibidem, s. 38.

48 J. Kristeva: Czarne stońce..., s. 68.

49 Ibidem.

${ }^{50}$ M.P. Маккоwsкi: Przygoda ciała i znaków. Wprowadzenie do pism Julii Kristevej. W: J. Kristeva: Czarne stońce..., s. XLV. 
twa i melancholii, czarnej żółci i czarnego słońca. W śląskim imaginarium zauważam jakąś osobność, odrębność, sprzeczność, którą wyraża tytułowy oksymoron. A zmierzch? W starej powstańczej pieśni zachód czerwonego słońca jest sygnałem przygotowania do boju, a noc rozdzielająca czas pokoju i wojny to okres tworzenia opowieści:

Tę piosenkę składali powstańcy

Śląscy szeregowcy

$\mathrm{W}$ dziewiętnastym roczku, w tym wielkim powstaniu, Przy jasnym miesiączku ${ }^{51}$

Zachód czarnego słońca sto lat po tamtych wydarzeniach wiążę, z jednej strony, z przejściem Górnego Śląska z fazy industrialnej w postindustrialną, z przejściem od Śląska Czarnego do Zielonego. Te przemiany łączą się, rzec jasna, ze zmianą mentalności i symboliki. Zniewalająca jest wszak siła czarnego złota, a porzucenie narracji industrialnych pionierów na rzecz opowieści porzuconych i pokalanych niezwykle trudne. Oczywiście opowieść o wspomnianym przejściu już się - nie bez komplikacji - snuje $\mathrm{e}^{52}$. Dużo silniejszy wydaje się etniczny nurt tej narracji - tu można tworzyć opowieść awansu i autonomii. To jednocześnie symbol wychodzenia z sieroctwa etnicznego (prawdziwego lub wyobrażonego), świadomości emancypacji własnej grupy ${ }^{53}$, i budowanie już nie połowicznego, a pełnego etnoobrazu ${ }^{54}$.

Piotr Śniedziewski, odtwarzając poetycki świat Nervala, pisze o świecie bez Boga, o niestabilnym wszechświecie, a wreszcie o pozornej epifanii, której rewelatorem staje się francuski poeta ${ }^{55}$.

Carl Gustaw Jung, ujawniając alchemiczne klucze do natury człowieka i świata, i utożsamiając Boga i Słońce, zauważa, że to

${ }^{51} \mathrm{Już}$ zachodzi czerwone słoneczko. https://bibliotekapiosenki.pl/utwory/Juz_zachodzi_czerwone_sloneczko/tekst [dostęp: 1.05.2019].

${ }^{52}$ Mam tu na myśli zorganizowanie szczytu klimatycznego COP 24 w Katowicach i towarzyszące temu wydarzeniu dyskusje.

${ }^{53}$ „Dyskusje w ramach grupy dowodzą tego, że wspólny obraz grupy, jej kultury, wspomnianej przeszłości i wizja przyszłości jeszcze nie zostały wypracowane (jeśli to w ogóle możliwe)". M. Szmeja: Śląsk bez zmian(?). Ludzie, kultura i społeczność Ślaska w perspektywie postkolonialnej. Kraków 2016, s. 264.

${ }^{54}$ Por. C.G. Jung: Mysterium Coniunctionis. Studia o dzieleniu i taczeniu przeciwieństw psychicznych w alchemii. Tłum. R. Reszke. Warszawa 2010, s. 135. Owa dwoistość życia psychicznego jest przed- i praobrazem symboliki Sol-Luna.

55 P. Śniedziewski: Czarne stońca..., s. 102-103. 
połączenie zdumiewająco trafnie oddają dystychy Anioła Ślązaka, chociażby ten:

Bóg jest mym ośrodkiem, gdy Go w sobie skrywam, A okręgiem wtedy, gdy się w nim rozpływam ${ }^{56}$.

I ta sfera niejednokrotnie śląskiemu bohaterowi pozwalała dojrzeć prawdziwą epifanię. Ale to temat na jeszcze inną opowieść.

\section{Bibliografia}

Bezruč P.: Ostrawa. Tłum. W. Zıемba-WojciechowsKa. W: 99 ksiażek, czyli mały kanon górnoślaski. Red. Z. KadŁubeK. Katowice 2011, s. 42-43.

Bieniasz S.: Niedaleko Königsalee. Katowice 1997.

BieŃczyK M.: Melancholia. O tych, co nigdy nie odnajda straty. Warszawa 2000.

Coster K. De: Przygody Dyla Sowizdrzała. Tłum. J. Rogoziński. Wrocław 1993.

Darowski J.: Unsere. Posłowie A. Jakubowska-OżóG. Rzeszów 2012.

Freud Z.: Żałoba i melancholia. W: Inem: Psychologia nieświadomości. Tłum. R. ReszKe. Warszawa 2007, s. 147-159.

Garve Ch.: O położeniu Ślaska w rozmaitym czasie oraz o zaletach stolicy względem miast prowincjonalnych. W: Śląsk. Rzeczywistości wyobrażone. Red. W. KUNICKI przy współpracy N. i K. ŻARskich. Poznań 2009, s. 101-113.

Gerlich M.: Śląska krzywda. „Etnografia Polska” 1994, z. 1-2, s. 5-24.

Grimmelshausen H.J.Chr. von: Przygody Simplicissiusa. Tłum. A.M. Linke. Warszawa 1958.

Jоснемсzүк M.: Wobec tradycji. Ślaskie szkice oikologiczne. Katowice 2015.

Jung C.G.: Mysterium Coniunctionis. Studia o dzieleniu $i$ łaczeniu przeciwieństw psychicznych w alchemii. Tłum. R. ReszKe. Warszawa 2010.

Już zachodzi czerwone słoneczko. https://bibliotekapiosenki.pl/utwory/Juz_zacho dzi_czerwone_sloneczko/tekst [dostęp: 1.05.2019].

KadŁubeK Z.: Utopijne utopce. „Fabryka Silesia” 2013, nr 1, s. 90-91.

Kalsched D.: Wewnętrzny świat traumy. Archetypiczne obrony Jaźni. Tłum. M. KALinOwsKa. Poznań 2015.

Kristeva J.: Czarne słońce. Depresja i melancholia. Tłum. M.P. Markowski, R. RYzIŃsKI. Kraków 2002.

Kuczok W.: Gnój. Warszawa 2010.

LaCapra D.: Trauma, nieobecność, utrata. Przeł. K. Bojarska. W: Antologia studiów nad trauma. Red. T. Łysak. Przeł. T. Bilczewski, K. Bojarska, J. Burzyński, A. Kowalcze-Pawlik, A. Rejniak-Majewska. Kraków 2015, s. 59-107.

Libera L.: Der Utopek. Roman. Dresden 2011.

Libera L.: Utopek. Tłum. S. Lisiecka. Łódź 2018.

${ }^{56}$ Za: ibidem, s. 149. 
Lysкo A.: Nasze dziedzictwo. Bieruń 2005.

Marchwitza H.: Moja młodość. Tłum. O. i A. Ziemińscy. Warszawa 1950.

Markowski M.P.: Przygoda ciała i znaków. Wprowadzenie do pism Julii Kristevej. W: J. Kristeva: Czarne słońce. Depresja i melancholia. Tłum. M.P. Markowski, R. RYZıŃski. Kraków 2002, s. V-XLIX.

Morcinek G.: Wyrabany chodnik. Wrocław 1997.

Nawarecki A.: Lajerman. Gdańsk 2010.

Nerval G. de: Aurelia. W: Idem: Śnienie i życie. Tłum. R. Engelking, T. Swoboda. Gdańsk 2012, s. 102-149.

Nerval G. De: El Desdichado. Tłum. A. WAżYк. W: Antologia współczesnej poezji francuskiej. Oprac. A. WАŻyK. Warszawa 1947, s. 26.

Nietzsche F.: Z genealogii moralności. Pismo polemiczne. Tłum. L. Staff. Kraków 2003.

NowaK H., Zivier G.: Zink wird Gold. Ein Roman des wirklichen Lebens. Berlin 1937.

Prokosz M.: Choroba sieroca. Gdańsk 2010.

Scholtis A.: Reise nach Polen. Ein Bericht. München 1963.

Scholtis A.: Wiatr od wschodu. Tłum. A. Smolorz. Kotórz Mały 2015.

SzewczyK W.: Czarne słońce. Warszawa 1953.

Szewczyk W.: Hanys. Noc. Katowice 1963.

Szmeja M.: Śląsk bez zmian(?). Ludzie, kultura i społeczność Ślaska w perspektywie postkolonialnej. Kraków 2016.

Szymutкo S.: Nagrobek ciotki Cili. Katowice 2001.

Śniedziewski P.: Czarne słońca romantyków. Warszawa 2018.

Twardoch S.: Wieczny Grunwald. Warszawa 2011.

VILlqIST I.: Czarne i zielone. „Fabryka Silesia” 2016, nr 1, s. 94-95.

WęGRZYNeK K.: Języki mitu, historii, religii na Górnym Ślasku. Katowice 2018.

WojaczeK R.: **[„,Ludzie kładą się spać...”]. W: Idem: Wiersze zebrane. Red. B. Kierc. Wrocław 2006.

ZIELONKA Z.: Śląsk - ogniwo tradycji. Katowice 1981.

Krystian Węgrzynek - doktor nauk humanistycznych, regionalista, publicysta, polonista. Pracuje w Instytucie Badań Regionalnych Biblioteki Śląskiej. Od 2011 roku działa w Komitecie Głównym Olimpiady Wiedzy o Górnym Śląsku. Od 2017 sekretarz Podyplomowych Studiów z Wiedzy o Regionie Uniwersytetu Śląskiego w Katowicach. Autor książki: Języki mitu, historii i religii w literaturze na Górnym Ślasku. Analiza wybranych dzieł XX wieku regionu pogranicza (Katowice 2018). Ostatnio opublikował Śmiech ślaskich bohaterów Tomasza Manna (w: Śmiech $i$ strach w literaturze $i$ sztuce przełomu XIX $i$ XX wieku. Red. H. Ratuszna, M. Kaźmierkiewicz, A. Łazicka. Toruń 2019).

e-mail: krystian.wegrzynek@gmail.com 